IRA-International Journal of Education \& Multidisciplinary Studies

ISSN 2455-2526; Vol.06, Issue 03 (2017)

Pg. no. 241-254

Institute of Research Advances

https://research-advances.org/index.php/IJEMS

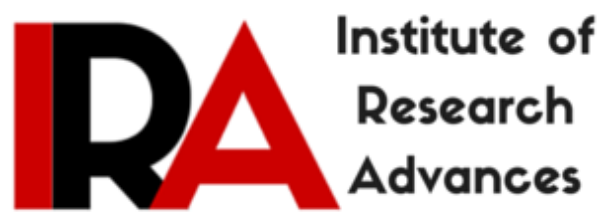

\title{
Effect of Co-Curricular Activities on Academic Achievement of Students
}

\author{
Ananya Singh \\ UGC-SRF, Department of Education, University of Allahabad \\ Allahabad -- 211002, Uttar Pradesh, India.
}

Type of Review: Peer Reviewed.

DOI: http://dx.doi.org/10.21013/jems.v6.n3.p4

\section{How to cite this paper:}

Singh, A. (2017). Effect of Co-Curricular Activities on Academic Achievement of Students. IRA International Journal of Education and Multidisciplinary Studies (ISSN 2455-2526), 6(3), 241-254. doi:http://dx.doi.org/10.21013/jems.v6.n3.p4

(C) Institute of Research Advances

\section{(cc) BY-NC}

This work is licensed under a Creative Commons Attribution-Non Commercial 4.0 International License subject to proper citation to the publication source of the work.

Disclaimer: The scholarly papers as reviewed and published by the Institute of Research Advances (IRA) are the views and opinions of their respective authors and are not the views or opinions of the IRA. The IRA disclaims of any harm or loss caused due to the published content to any party. 


\begin{abstract}
Development of child's body and mind demand proper nurturing of its physical and intellectual qualities as few of the major determinants of his personality. Therefore, modern approaches of education emphasize on all round development of the child. The process of education is not something static or one time measure rather, continuous and life long endeavor that can be divided in two parts; curricular activities and co-curricular activities. . Co-curricular activities, as the name implies, are those, not directly related with the prescribed curriculum and include; sports, athletics, scouting, cubing, various hobbies, excursions literary societies, dramatics, debates etc. to bring social and physical adjustments in the child.

The study concluded that in wholesome the overall effect of co-curricular activities on the student's academic performance and personality development is positive. And it compliments the academic activities in attainment of education's main goal of bringing change in student's behavior.
\end{abstract}

\title{
INTRODUCTION
}

The function of education is to bring change in child behavior and personality in a more desirable form. These are also recognized as a source of enrichment and vitalization of the schools curriculum, mainly through the cultivation of hobbies, interests, etc. these activities are no longer looked upon as extras but as an integral part of the school program. The distinction between curricular and extra curricular is gradually disappearing in modern educational practice and the coordination and integration of all the experiences of the pupils' intellectual, social, moral, emotional and physical abilities has become the object of the persistent efforts of the school. Co-curricular activities, as the name implies, are those, not directly related with the prescribed curriculum and include; sports, athletics, scouting, cubing, various hobbies, excursions literary societies, dramatics, debates etc. to bring social and physical adjustments in the child. The basic idea behind such activities in educational institutions is the building up of the student character and personality as well as training of their mind that may help / facilitate academic achievements of the child.

One of the early philosophies behind co-curricular activities was that they should, wherever at all possible, "grow out of curricular activities and return to curricular activities to enrich them" (Millard, 1930, page. 12). Eventually people, including educators, began to see the benefits of co-curricular activities, but it took a while to inure themselves. In fact, before 1900, educators were skeptical of participation in extracurricular activities, believing that "school should focus solely on narrowly defined academic outcomes. Non-academic activities were viewed as being primarily recreational and therefore were detrimental to academic achievement, and consequently were discouraged" (Marsh \& Kleitman, 2002).

Co-curricular activities (CCAs), previously known as Extracurricular Activities (ECA) are activities that educational organizations in some parts of the world create for school students. They are activities which all school students must attend alongside. In Singapore, the policy was introduced by the Ministry of Education, which believes extra activities for school students are a means to enhance social interaction, leadership, healthy recreation, self-discipline and self-confidence. At higher levels of education, CCA participation may even translate into academic points.

Co-curricular activities are also referred as Extra-curricular activities. Grammatically, there is a difference between the two. Extra-curricular is self explanatory, i.e. Activities which are extra or additional to curricular but is more leisure oriented than learning oriented. Extra-curricular activities are mostly conducted after school hours. They generally don't complement academic studies. However, some of the activities overlap each other, some extra -curricular activities are considered co-curricular while for some it is extra-curricular.

It helps to develop the all-round personality of the students to face the undaunted task and turbulent world of future. Experience and accolades gained through many of these activities help during internships and other school sponsored work programs. The aim of curricular activities is to make the 
students fit for the future time and to develop a sense of competitive spirit, co-operation, leadership, diligence, punctuality, team- spirit as well as to provide a backdrop for the development of their creative talents. Additional activities for schools students are a means to enhance social interaction, leadership, healthy recreation, self-discipline and self confidence. Competitions may also be organized to create a competitive environment and groups with an objective to work towards a better society and the world as well.

Some researchers have divided co-curricular activities into informal and formal activities. The formal activities include activities which are relatively structured, such as participating in athletics or learning to play a musical instrument. Informal activities, on the other hand, also known as leisure activities, include less structured activities, such as watching television. Some literature on leisure studies has "suggested that formal and informal activity settings have different influences on motivation and feelings of competence," two factors which influence academic performance (Guest \& Schneider, 2003, para. 8). One study found "that more time in leisure activities was related to poorer academic grades, poorer work habits, and poorer emotional adjustments," while more time in "structured groups and less time watching TV were associated with higher test scores and school grades".

Academic achievement is the outcome of education — the extent to which a student, teacher or institution has achieved their educational goals. Academic achievement is commonly measured by examinations or continuous assessment but there is no general agreement on how it is best tested or which aspects are most important — procedural knowledge such as skills or declarative knowledge such as facts.

\section{REVIEW OF RELATED LITERATURE}

Shepard, 1996, para. 12. - Some research indicates that physical activity not only improves academic performance, but has an actual physical benefit for the mind. Said, "Regular physical activity might influence cognitive development by increasing cerebral blood flow, altering arousal and associate neurohormonal balance, changing nutritional status, or promoting the growth of internal neuronal connections".

Brown, Cozby, Kee, \& Worden (1999, page.75). - All of these activities appear to have some sort of effect on students' academic performance; however, the issue of whether they benefit or hinder is unknown. The research would be described as a descriptive study because it observes behaviors "as they occur naturally, describes behavior, explores a phenomenon, and tests hypotheses about behavior" Therefore, the purpose of this study was to determine whether or not the activities that students choose have an effect on their academic performance.

Ponter (1999, para. 1). - Studies reflect a strong positive relationship between participation in music and academic performance. They suggested that "music should be considered as fundamental to the curriculum as mathematics and reading".

Simon (2001, para. 1). - In addition to co-curricular or extracurricular activities, "analyses revealed that regardless of students' background and prior achievement, various parenting, volunteering, and home learning activities positively influenced student grades"). Numerous studies have examined the factors influencing students' academic achievement, and many activities were found to have a significant influence.

Broh (2002, para. 8). - Numerous studies have been conducted concerning the relationship between extracurricular activities and academic performance. Total extracurricular activity participation (TEAP), or participation in extracurricular activities in general, is associated with an improved grade point average, higher educational aspirations, increased college attendance, and reduced absenteeism". 
Broh (2002, para. 3). - "Early analysis of the effect of participation in sports on academic achievement produced inconsistent evidence"). Even today, there is inconsistent evidence, but most research tends to lean toward the idea that participation in athletics does, in fact, improve academic performance. The result of one particular study indicated that "with the exception of a few subgroups and outcomes, participation in sports is generally unrelated to educational achievement." Additional information from this study has "found that playing sports in high school has no significant effect on grades or standardized test scores in the general student population" (para. 5). Although this particular study produced a negative relationship between sports and academic performance, many demonstrate a positive relationship.

Schaben (2002, para. 4). - Music, parental involvement, sports-all of these have an influence on how children perform academically. The way children choose to spend their free time can affect their school performance; it is not simply traditional in-class instruction that impacts academic achievement. "A study by the U. S. Department of Education revealed that students who participate in co-curricular activities are three times more likely to have a grade point average of 3.0 or better" than students who do not participate in co-curricular activities.

Stephens \& Schaben (2002, para. 2). - School principals are interested in the "relationship between academic achievement and participation in interscholastic sports at middle level schools," implying that sports do have some sort of influence on how students perform academically.

Stephens \& Schaben (2002, para. 6). - They performed a study looking at the number of sports each student played and its affect on academic performance. They noticed that students who participate in at least one sport each year outperformed those who participated in one or less, in class rank, overall GPA, and math GPA They also noticed that the students who participated in more sports for many seasons had a "higher level of scholarship than the students who had competed in only a few seasons or for only one year" (para. 7).

Darling, Caldwell, \& Smith (2005, para. 1). - Researchers have particularly studied the relationship between extracurricular activities and academic performance in adolescents. One study found that "adolescents who participated in extracurricular activities reported higher grades, more positive attitudes toward school, and higher academic aspirations". They further conducted a longitudinal study concerning extracurricular activities and their effect on various aspects of development, including academic performance. A survey containing a list of twenty different extracurricular activities was distributed to students; they were asked to check which extracurricular activities they participated in that year. Demographic questions, such as their favorite activity, gender, and ethnicity were asked in order to take the social factors and influences into account when calculating the results. The students were also asked what their academic goals were and their grade point average. The results showed that the students who participated in school-based extracurricular activities had higher grades, higher academic aspirations, and better academic attitudes than those who were not involved in extracurricular activities at all.

Darling et al. (2005, para. 40). - found that students who did not participate in any extracurricular activities showed the poorest adjustment as far as grades, attitude toward school, and academic aspirations, while non-sport extracurricular activities showed the most positive adjustment, with sports related extracurricular activities in the middle.

\section{THE STUDY}

\section{INSTRUMENTATION:}

The tool used for data collection of the present study was the checklist developed by the researcher itself. The present study aimed at finding the impact of co-curricular activities on the academic achievement of students; therefore selection of the tool was of great significance for the researcher. The 
researcher reached many sources and sites and prepared the tool. This tool was found to be appropriate and statistically acceptable for studying the relationship between academic achievement and co-curricular activities of students. In a research different instruments/tools are used to test the hypothesis. In present study for data collection the researcher used the checklist. In this tool, on first sheet background information of students were asked, then 45 co-curricular activities were listed .students have to mark right if they have ever participated in their previous classes followed by a table, where they have to fill their marks obtained in the $10^{\text {th }}$ class board examination. The tool is given in the appendix -1 .

\section{SAMPLING:}

The population for the study consisted of $11^{\text {th }}$ class students of schools of Allahabad city. Non-probability sampling method was adopted for the selection of the sample for the present study. The sample consisted of a total 100 students, in which 30 were boys and 70 were girls. The sample was taken from Allahabad city. The students taken for the study of the present research were identical in geographical location, board of study, socio-economic background.

\section{DATA ANALYSIS:}

Total numbers of participation out of all 45 items were added for each students and their marks in all 4 subjects were also listed separately as well as total. For the collection of the data the researcher let the respondents be seated in natural classroom environment. The purpose of the study was clearly presented before the students and carefully instructed regarding the checklist given to the students. To find out the impact of the 45 items of co-curricular activities on the academic achievement of students, data was collected from 100 students from both the gender and correlation coefficient was computed between level of participation in co-curricular activities and academic achievement in different subjects by Pearson Product Moment Method and their significance was tested at the level of 0.05 and 0.01 . The significance difference between Correlation Coefficient between boys and girls were also computed by t- test.

\section{FINDINDS AND CONCLUSION}

\section{COMPERISION OF LEVEL OF PARTICIPATION BETWEEN BOYS AND GIRLS IN VARIOUS CO-CURRICULAR ACTIVITIES:}

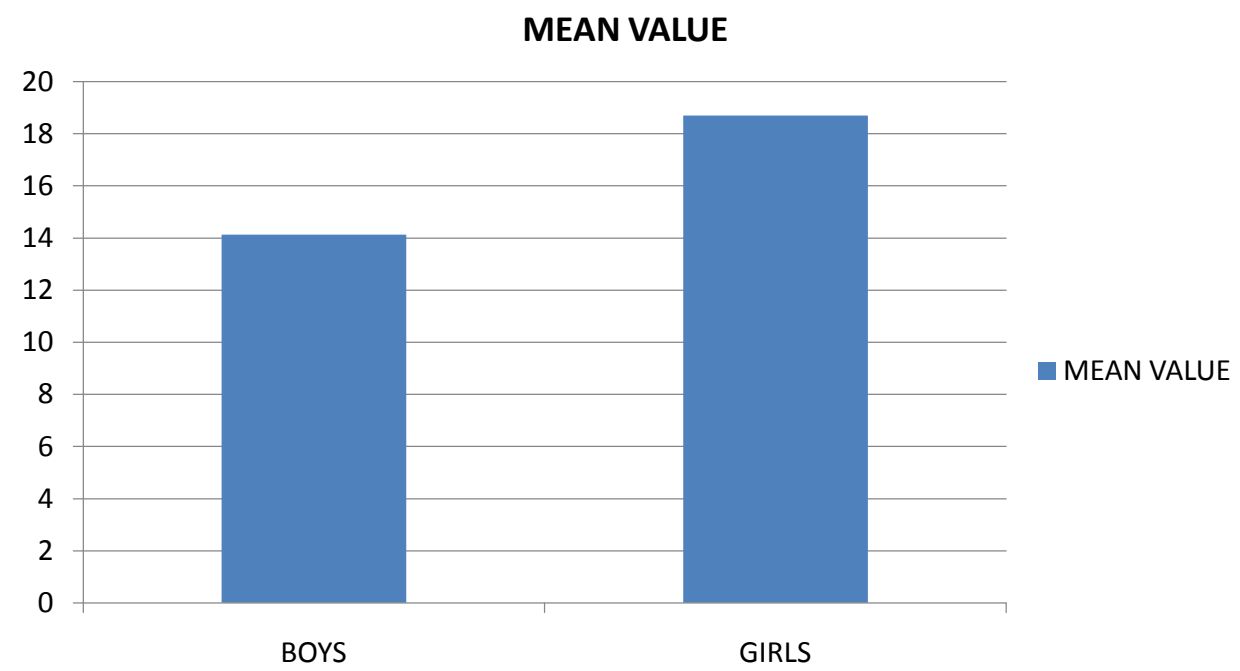


There is significant difference between the level of participation in different co-curricular activities.

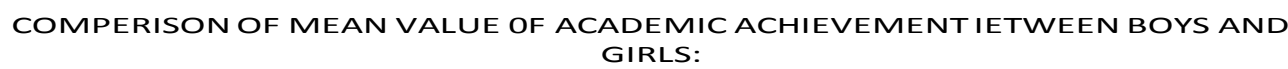
GIRLS:

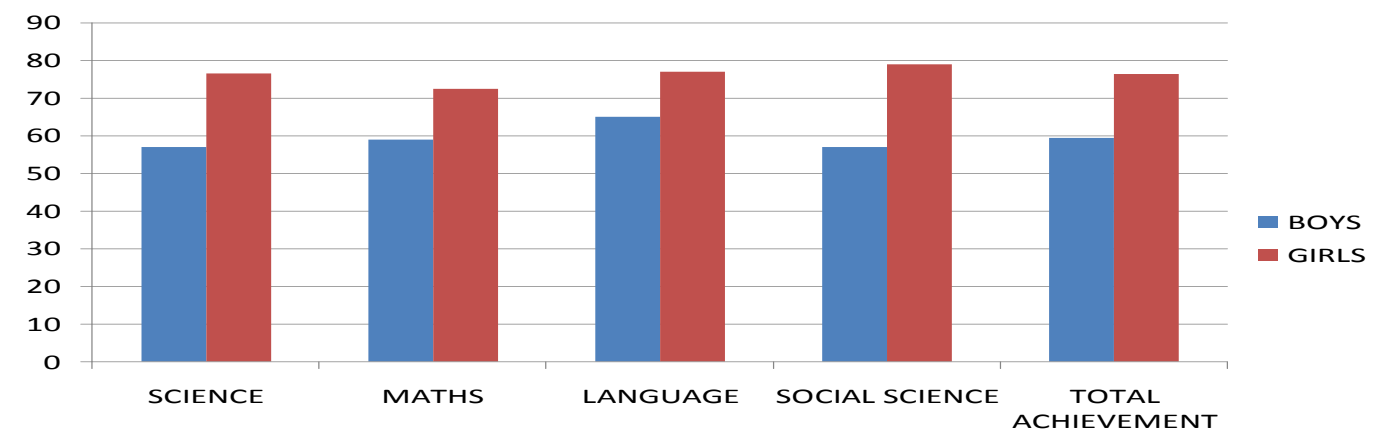

There is significant difference between the academic achievement of boys and girls in various subjects as low correlation between the academic achievement in science subject and level of participation in co-curricular activities of students and here is significant relationship between the academic achievement in mathematics and level of participation in co-curricular activities of students. There is also significant relationship between the academic achievement in language and social sciences subject and level of participation in co-curricular activities of students. There is not significant difference between the correlation coefficient of boys and girls in academic achievement in science and language subjects and level of co-curricular activities. But there is significant difference between the correlation coefficient of boys and girls in academic achievement in mathematics and social sciences level of co-curricular activities.

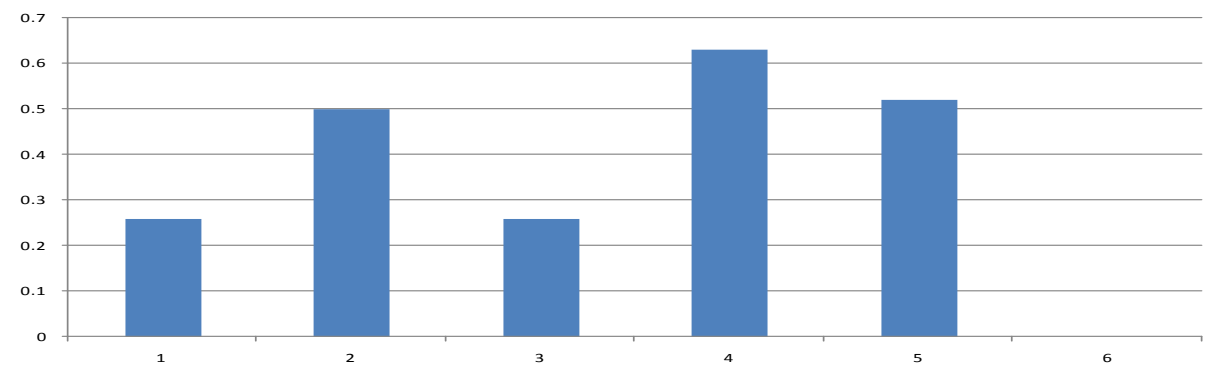

Graph 1. showing the correlation coefficient value in different subjects as

1. SCIENCE

2. MATHEMATICS

3.LANGUAGE

4.SOCIAL SCIENCE

5. AGGREGATE OF ALL FOUR SUBJECT.

So, finally we can conclude that students (boys and girls) have differences in their academic achievement in various subjects and also have differences in their level of participation in co-curricular activities. Student's academic achievements in different subjects are positively affected by their different level of participation in co-curricular activities; specially this trend is high in the girls in comparison to the boys.

The study concluded that in wholesome the overall effect of co-curricular activities on the student's academic performance and personality development is positive. And it compliments the academic 
activities in attainment of education's main goal of bringing change in student's behavior. Co-curricular activities do not obstruct in academic out put rather it facilitates in increasing their knowledge and develops competitive spirit that foster students resolve in examinations. Students taking part in co-curricular activities mostly carry healthy habits and appreciable potential of social adjustment.

\section{References:}

1. Andy Zehner, (2011), "Co-Curricular Activities \& Student Learning Outcomes".

2. Best and Kahn, Research in Education, PHI learning Private Limited, 2009.

3. Gruher F.C. and Beatty T.B., (1954) Seconday school activities, New York: McGraw Hill Book Co.

4. Hoolingworth P.M. and Kenneth H. Hoover, (1991), Elementary teaching methods, Boston : Allen and Bacon.

5. Ismat, Rakhsi Saleem, "Role of Co-Curricular Activities: Survey of the Perceptions of Stake Holders (Case Study of Peshawar District)", Journal of Managerial Sciences Volume II, Number 2.

6. Israel Kariyana, Cosmas Maphosa and Beginner Mapuranga (2012) "The Influence of Learners' Participation in School Co-curricular Activities on Academic Performance: Assessment of Educators' Perceptions", J Soc Sci, 33(2): 137-140.

7. MHRD, Learning without Burden., (1993) Govt. of India, MHRD, Department of Education.

8. MHRD, National policy on education (1986), New Delhi: Govt, of India, MHRD, Deptt. of Education, 1986 and revised 1992.

9. MHRD, Programme of action (1992) National Policy on Education, Department of Education, 1992.

10. Storey, Katie Lauren, "Bridging the Gap: Linking Co-Curricular Activities to Student Learning Outcomes in Community College Students" (2010). Dissertations. Paper 30.

11. Zahid Bashir, Shafqat Hussain, (2012), "The Effectiveness of Co-curricular Activities on Academic Achievements of Secondary School Students in District Abbottabad Pakistan- A Case Study", Vol 3, No 1. 


\section{APPENDICES}

APPENDIX - 1:

THE EFFECT OF CO-CURRICULAR ACTIVITIES ON ACEDEMIC ACHIEVEMENT OF STUDENT

\section{BACKGROUND INFORMATION -}

NAME

AGE.

YOUR SCHOOL IS PRIVATE / GOVERNMENT

GENDER

NAME OF GUARDIAN

JOB OF GUARDIAN

FAMILY INCOME

\begin{tabular}{|l|l|}
\hline Upto $10,000 /$ month & \\
\hline $10,000-30,000 /$ month & \\
\hline Above $30,000 /$ month & \\
\hline
\end{tabular}

MOTHER'S NAME

MOTHER'S JOB

Dear Friends,

There are 45 items regarding your participation in co-curricular activities. [ $\sqrt{ }]$ Mark in those items in which you have participated. Feel free to respond each items. The information will be used for the research purposes only. Also give the marks obtained by you in the previous class.

\begin{tabular}{|l|l|l|l|}
\hline S.N. & \multicolumn{1}{|l|}{ CO-CURRICULAR ACTIVITIES } & \multicolumn{2}{l|}{ PARTICIPATION STATUS } \\
\hline & \multicolumn{1}{|l|}{ YES } & & NO \\
\hline 1. & Athletics & & \\
\hline 2. & Boating & \\
\hline 3. & $\begin{array}{l}\text { Book reading (story books, comics, novels } \\
\text { etc.) }\end{array}$ & & \\
\hline
\end{tabular}




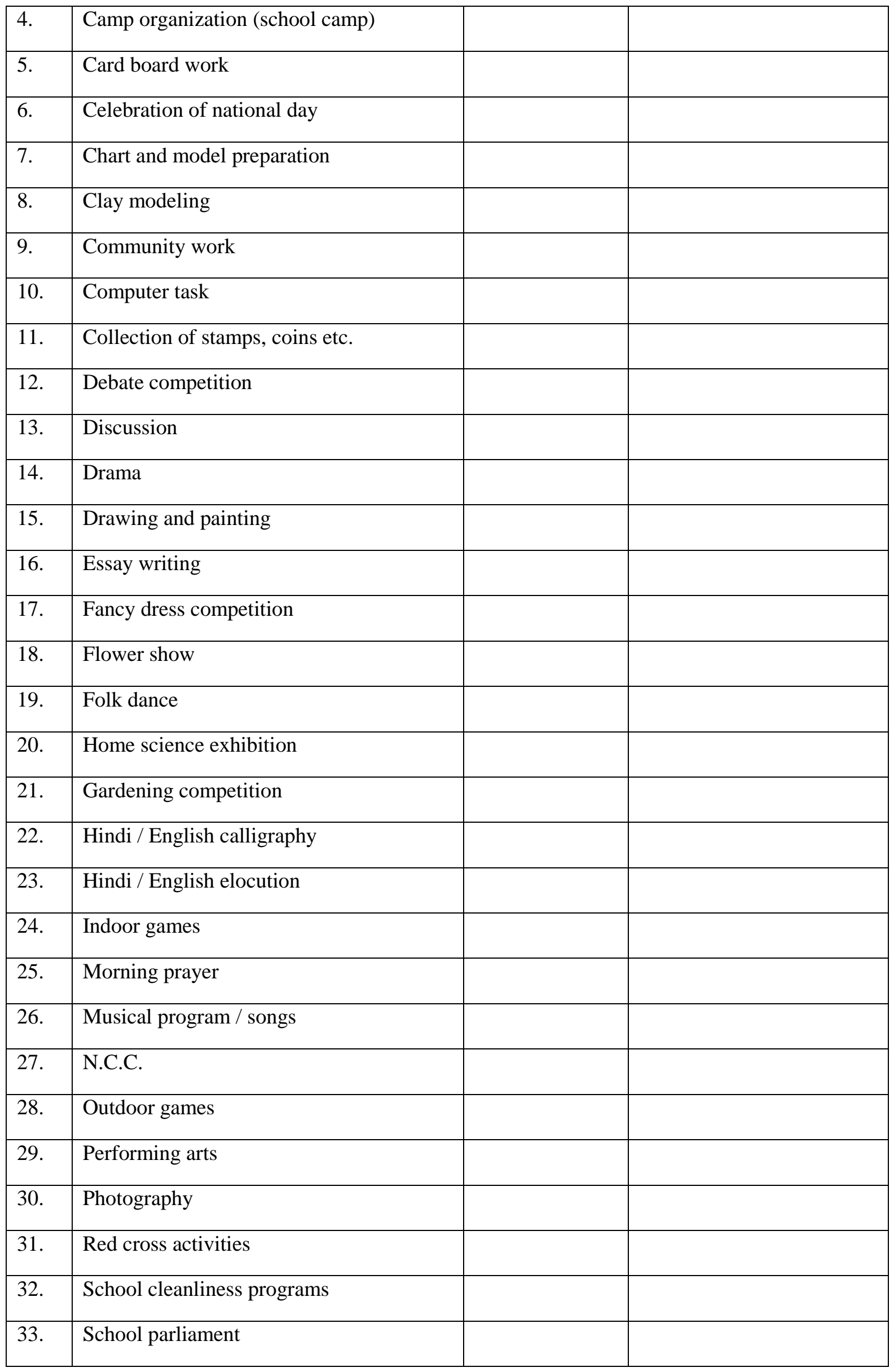




\begin{tabular}{|l|l|l|l|}
\hline 34. & School exhibition & & \\
\hline 35. & School decoration & & \\
\hline 36. & Science fairs, clubs & & \\
\hline 37. & Scouting and guiding & & \\
\hline 38. & Sculpture & & \\
\hline 39. & Social service activities & & \\
\hline 40. & Speech competition & & \\
\hline 41. & Story writing competition & & \\
\hline 42. & Swimming & & \\
\hline 43. & Symposium & & \\
\hline 44. & Visit to any historical places & & \\
\hline 45. & Yogic asanas & & \\
\hline
\end{tabular}

MARKS OBTAINED BY YOU IN YOUR BOARD EXAMINATION IN THE FOLLOWING SUBJECTS

\begin{tabular}{|l|l|}
\hline SUBJECTS & MARKS OBTAINED (in \%) \\
\hline Science & \\
\hline Mathematics & \\
\hline Literature / Language & \\
\hline Social science & \\
\hline
\end{tabular}

*Kindly attach a single Xerox copy of your board exam mark sheet.

DATE

SIGNATURE 
APPENDIX 2:

LEVEL OF PARTICIPATION OF BOYS IN CO-CURRICULAR ACTIVITIES AND THEIR OBTAINED MARKS IN DIFFERENT SUBJECTS:

\begin{tabular}{|c|c|c|c|c|c|c|}
\hline $\begin{array}{l}\text { SR. } \\
\text { NO. }\end{array}$ & $\begin{array}{l}\text { LEVEL OF } \\
\text { PARTICIPATION }\end{array}$ & SCIENCE & MATHS & LANGUAGE & $\begin{array}{l}\text { SOCIAL } \\
\text { SCIENCES }\end{array}$ & TOTAL \\
\hline 1 & 30 & 63 & 59 & 70 & 65 & 64.25 \\
\hline 2 & 20 & 86 & 74 & 88 & 78 & 81.50 \\
\hline 3 & 20 & 42 & 54 & 44 & 42 & 45.50 \\
\hline 4 & 11 & 58 & 64 & 72 & 64 & 64.50 \\
\hline 5 & 15 & 60 & 60 & 70 & 60 & 62.50 \\
\hline 6 & 18 & 38 & 46 & 78 & 40 & 50.50 \\
\hline 7 & 11 & 66 & 60 & 69 & 42 & 59.25 \\
\hline 8 & 20 & 58 & 35 & 60 & 42 & 48.75 \\
\hline 9 & 13 & 40 & 54 & 52 & 35 & 45.25 \\
\hline 10 & 3 & 54 & 60 & 58 & 60 & 58 \\
\hline 11 & 12 & 66 & 42 & 76 & 58 & 60.50 \\
\hline 12 & 25 & 78 & 94 & 72 & 90 & 83.50 \\
\hline 13 & 21 & 66 & 86 & 78 & 80 & 77.5 \\
\hline 14 & 18 & 42 & 44 & 7 & 48 & 52 \\
\hline 15 & 16 & 38 & 54 & 60 & 50 & 50.5 \\
\hline 16 & 24 & 44 & 76 & 66 & 54 & 45 \\
\hline 17 & 12 & 35 & 35 & 58 & 38 & 52.25 \\
\hline 18 & 35 & 38 & 45 & 48 & 38 & 42.25 \\
\hline 19 & 8 & 44 & 20 & 40 & 21 & 31.25 \\
\hline 20 & 23 & 74 & 76 & 76 & 80 & 76.5 \\
\hline 21 & 18 & 64 & 88 & 76 & 64 & 73 \\
\hline 22 & 10 & 40 & 46 & 58 & 42 & 46.5 \\
\hline 23 & 16 & 46 & 23 & 48 & 26 & 35.75 \\
\hline 24 & 22 & 43 & 61 & 64 & 52 & 55 \\
\hline 25 & 11 & 57 & 8 & 57 & 57 & 54.75 \\
\hline
\end{tabular}


IRA-International Journal of Education \& Multidisciplinary Studies

\begin{tabular}{|l|l|l|l|l|l|l|}
\hline 26 & 8 & 53 & 51 & 62 & 69 & 58.75 \\
\hline 27 & 16 & 69 & 63 & 70 & 76 & 69.5 \\
\hline 28 & 16 & 81 & 89 & 79 & 83 & 83 \\
\hline 29 & 8 & 78 & 80 & 52 & 75 & 71.25 \\
\hline 30 & 34 & 86 & 80 & 81 & 83 & 82.5 \\
\hline
\end{tabular}

\section{APPENDIX - 3:}

LEVEL OF PARTICIPATION OF GIRLS IN CO-CURRICULAR ACTIVITIES AND THEIR OBTAINED MARKS IN DIFFERENT SUBJECTS:

\begin{tabular}{|c|c|c|c|c|c|c|}
\hline $\begin{array}{l}\text { SR. } \\
\text { NO. }\end{array}$ & $\begin{array}{l}\text { LEVEL OF } \\
\text { PARTICIPATION }\end{array}$ & SCIENCES & MATHS & LANGUAGE & $\begin{array}{l}\text { SOCIAL } \\
\text { SCIENCES }\end{array}$ & TOTAL \\
\hline 1 & 30 & 84 & 84 & 87 & 82 & 84.25 \\
\hline 2 & 24 & 82 & 74 & 80 & 84 & 80 \\
\hline 3 & 28 & 75 & 80 & 65 & 65 & 71.25 \\
\hline 4 & 15 & 85 & 65 & 87 & 84 & 80.25 \\
\hline 5 & 30 & 83 & 55 & 77 & 83 & 74.5 \\
\hline 6 & 5 & 80 & 95 & 86 & 84 & 86.25 \\
\hline 7 & 21 & 75 & 70 & 85 & 78 & 76.75 \\
\hline 8 & 4 & 69 & 56 & 63 & 66 & 63.50 \\
\hline 9 & 16 & 85 & 59 & 87 & 85 & 79 \\
\hline 10 & 25 & 85 & 85 & 82 & 85 & 84.25 \\
\hline 11 & 25 & 84 & 64 & 86 & 85 & 79.75 \\
\hline 12 & 27 & 85 & 82 & 93 & 85 & 86.25 \\
\hline 13 & 20 & 84 & 67 & 80 & 85 & 79 \\
\hline 14 & 45 & 85 & 95 & 96 & 87 & 90.75 \\
\hline 15 & 21 & 85 & 83 & 79 & 85 & 83 \\
\hline 16 & 22 & 78 & 75 & 92 & 74 & 79.75 \\
\hline 17 & 11 & 79 & 88 & 78 & 74 & 79.75 \\
\hline 18 & 20 & 82 & 73 & 62 & 82 & 74.75 \\
\hline 19 & 5 & 69 & 72 & 66 & 75 & 70.50 \\
\hline
\end{tabular}


IRA-International Journal of Education \& Multidisciplinary Studies

\begin{tabular}{|c|c|c|c|c|c|c|}
\hline 20 & 28 & 73 & 79 & 68 & 82 & 75.50 \\
\hline 21 & 12 & 85 & 914 & 79 & 84 & 85.50 \\
\hline 22 & 30 & 83 & 57 & 86 & 83 & 77.25 \\
\hline 23 & 30 & 80 & 78 & 64 & 83 & 76.25 \\
\hline 24 & 20 & 85 & 71 & 89 & 87 & 83 \\
\hline 25 & 19 & 82 & 76 & 67 & 85 & 77.50 \\
\hline 26 & 11 & 71 & 71 & 70 & 80 & 73 \\
\hline 27 & 24 & 85 & 84 & 70 & 81 & 80 \\
\hline 28 & 4 & 60 & 62 & 71 & 68 & 65.25 \\
\hline 29 & 1 & 85 & 70 & 79 & 85 & 82.25 \\
\hline 30 & 26 & 89 & 80 & 80 & 85 & 83.50 \\
\hline 31 & 8 & 73 & 80 & 69 & 77 & 74.75 \\
\hline 32 & 8 & 85 & 84 & 98 & 82 & 87.25 \\
\hline 33 & 31 & 79 & 61 & 76 & 71 & 71.75 \\
\hline 34 & 22 & 82 & 82 & 81 & 82 & 81.75 \\
\hline 35 & 26 & 85 & 82 & 80 & 88 & 83.75 \\
\hline 36 & 6 & 85 & 75 & 87 & 85 & 83 \\
\hline 37 & 17 & 84 & 85 & 75 & 84 & 82 \\
\hline 38 & 25 & 79 & 79 & 69 & 84 & 77.75 \\
\hline 39 & 15 & 56 & 64 & 51 & 54 & 56.25 \\
\hline 40 & 16 & 82 & 74 & 71 & 83 & 77.50 \\
\hline 41 & 36 & 85 & 70 & 89 & 85 & 82.25 \\
\hline 42 & 33 & 85 & 84 & 84 & 84 & 84.25 \\
\hline 43 & 25 & 69 & 52 & 84 & 87 & 73 \\
\hline 44 & 16 & 60 & 80 & 72 & 61 & 68.25 \\
\hline 45 & 15 & 84 & 62 & 69 & 84 & 74.75 \\
\hline 46 & 14 & 69 & 59 & 64 & 69 & 65.25 \\
\hline 47 & 17 & 73 & 68 & 85 & 71 & 74.25 \\
\hline 48 & 20 & 78 & 86 & 79 & 82 & 81.25 \\
\hline 49 & 6 & 62 & 74 & 86 & 79 & 75.25 \\
\hline
\end{tabular}


IRA-International Journal of Education \& Multidisciplinary Studies

\begin{tabular}{|c|c|c|c|c|c|c|}
\hline 50 & 28 & 88 & 76 & 88 & 85 & 84.25 \\
\hline 51 & 26 & 80 & 86 & 77 & 80 & 80.25 \\
\hline 52 & 2 & 69 & 56 & 73 & 75 & 68.25 \\
\hline 53 & 4 & 67 & 71 & 74 & 68 & 70 \\
\hline 54 & 4 & 58 & 69 & 76 & 76 & 69.75 \\
\hline 55 & 16 & 85 & 78 & 89 & 82 & 83.5 \\
\hline 56 & 29 & 82 & 87 & 80 & 78 & 81.75 \\
\hline 57 & 31 & 90 & 84 & 86 & 85 & 86.25 \\
\hline 58 & 8 & 57 & 60 & 66 & 68 & 62.75 \\
\hline 59 & 11 & 42 & 38 & 58 & 46 & 46 \\
\hline 60 & 25 & 77 & 79 & 92 & 76 & 81 \\
\hline 61 & 5 & 78 & 60 & 86 & 48 & 68 \\
\hline 62 & 15 & 69 & 60 & 80 & 69 & 69.5 \\
\hline 63 & 35 & 83 & 83 & 86 & 85 & 84.25 \\
\hline 64 & 14 & 50 & 58 & 62 & 70 & 60 \\
\hline 65 & 7 & 72 & 81 & 68 & 70 & 72.75 \\
\hline 66 & 19 & 46 & 64 & 52 & 42 & 51 \\
\hline 67 & 14 & 72 & 78 & 71 & 84 & 76.25 \\
\hline 68 & 24 & 85 & 83 & 93 & 85 & 86.5 \\
\hline 69 & 30 & 85 & 90 & 93 & 84 & 88 \\
\hline 70 & 7 & 50 & 50 & 72 & 72 & 61 \\
\hline
\end{tabular}

